Article Review

\title{
Penyebaran dan Manfaat Ekonomi Bulu Babi Diadema Setosum di Perairan Indonesia
}

\author{
Firanda Lapamudi* \\ *Jurusan Manejemen Sumber Daya Perairan, Fakultas Perikanan dan IImu Kelautan, Universitas Negeri Gorontalo, \\ Indonesia. Email: firandalapamudi@gmail.com
}

\section{Introduction}

Indonesia merupakan negara kepulauan yang dikenal memiliki kekayaan alam baik flora maupun fauna yang sangat banyak. Ekosistem pesisir maupun laut menyediakan sumber daya alam yang sangat banyak manfaatnya baik sebagai sumber makanan, sumber kehidupan, sumber mineral dan kawasan rekreasi ataupun pariwisata (Bengen, 2000 dalam Yudasmara, 2013 ). Dilihat dari sudut pandang ekologis, wilayah pesisir mempunyai nilai sumberdaya alam yang tinggi dan merupakan ekosistem yang lengkap. Sumberdaya alam yang ada di kawasan pesisir ialah pasir, air laut, mineral laut, mikroorganisme, mangrove, terumbu karang, padang lamun, dan perikanan (Fitriansyah, 2018). salah satu ekosistem pesisir yang mempunyai produktivitas primer relatif tinggi serta memiliki peranan yang penting untuk menjaga kelestarian dan keanekaragaman organisme laut yaitu ekosistem padang lamun. Biota laut yang berasosiasi di padang lamun salah satunya bulu babi (Riniatsih dan Munasik, 2017)

Bulu babi atau Sea urchin merupakan biota yang termasuk ke dalam kelompok echinodermata yang tersebar dari daerah pasang surut hingga ke laut dalam. (Nystrom et al, 2000 dalam Miala, 2015). Bulu babi adalah salah satu termasuk spesies keystone species bagi kelompok terumbu karang (Nystrom, 2000). Menurut Lawrence, (1975 dalam Moningkey, 2010) bulu babi adalah salah satu biota yang termasuk sebagai penentu kelimpahan dan sebaran tumbuhan di perairan laut yang dangkal. Echinodermata (bulu babi) berasal dari bahasa Yunani Echinos artinya duri, derma artinya kulit. Jadi, echinodermata adalah penghuni perairan dangkal, pada umumnya terdapat di area terumbu karang dan padang lamun. Hal ini karena bulu babi adalah salah satu pengendali populasi mikroalga. Tingginya tutupan vegetasi lamun di perairan memungkinkan kehadiran berbagai biota yang berasosiasi dengan ekosistem padang lamun termasuk bulu babi hal ini berfungsi untuk tempat hidup, mencari makan, memijah dan tempat berlindung untuk menghindari predator (Supono dan Arbi, 2010 dalam Setyawan, 2014).

Echinoidea adalah Salah satu kelas yang terdapat dalam filum Echinodermata yang salah satunya itu bulu babi. Bulu babi pada umumnya hidup di kawasan wilayah terumbu karang (Nane 
dkk., 2020), padang lamun, dan juga pasir (Afifa, 2017). Habitat dari spesies echinoidea khususnya yaitu Padang lamun, pasir, terumbu karang, substrat dan substrat yang keras. Dikarenakan, area tersebut menyediakan sumber makanan atau lebih tepatnya sangat banyak makanan yang ditemui di area tersebut dan juga sebagai tempat berlindung bagi echionoidae khususnya bulu babi tersebut (Yusron, 2009 dalam Ayuwatu, 2017).

Bulu babi memiliki kebiasaan pola hidup berkelompok atau bergerombol (beragregasi) dan jenis hewan ini seringkali terjebak di daerah terumbu yang rata pada saat surut (Aziz, 1988 dalam Lubis, 2017; Nane, 2019d). Berbeda halnya dengan kelompok ular, teripang dan bintang laut. Bulu babi ini tidak mengenal cara adaptasi untuk menghindari dirinya dari sengatan matahari. Kelompok inilah yang banyak dilaporkan atau banyak informasi mengalami kematian massal diakibatkan suhu ekstrim di atas ambang batas (Purwandatama, 2013 dalam Lubis, 2017). Karena, Bulu babi umumnya hewan nocturnal atau biasanya hewan yang aktif pada malam hari, sepanjang siang mereka akan bersembunyi di celah-celah karang pada saat malam hari mereka aktif akan keluar dengan tujuan untuk mencari makanan (Zakaria, 2013: 384 dalam Lubis, 2017).

Umumnya setiap jenis bulu babi mempunyai sebaran habitat yang spesifik atau khusus (Jeng,1998 dalam Firmandana, 2014). Menurut De Beer (1990 dalam Juliawan, 2017), bahwa secara luas penyebaran pada bulu babi sangat tergantung pada faktor habitat dan makanan. Khusus untuk spesies E. mathaei dan E. calamaris hidupnya menyendiri dilubang karang untuk menghindari dirinya dari para predator. Hal ini sesuai dengan pernyataan Aziz (1996 dalam Juliawan, 2017), yaitu ada beberapa jenis bulu babi yang hidup menyendiri antara lain E. calamaris, E.mathaei, dan pada kelompok karang mati juga sering ditemukan bulu babi spesiesnya yaitu $E$. calamaris. Menurut Nybakken Gani et al, (2013 dalam Puspitaningtyas, 2018). Penyebaran merupakan suatu bentuk secara individu yang satu relative terhadap biota yang lain dalam populasi. Penyebaran jenis biota laut seperti bulu babi dan hewan-hewan lainnya di sebabkan karena kondisi lingkungan itu sendiri. Oleh sebab itu, bulu babi dapat hidup dan tumbuh menyebar di perairan pantai seiring dengan lingkungan yang mempengaruhinya. Bulu babi ini menyebar di daerah tertentu seperti pada terumbu karang, lamun, mangrove dan ganggang (Suwigyo et al., 2005 dalam Puspitaningtyas, 2018).

Di perairan Indonesia, Filipina, Malaysia, maupun juga pada wilayah Australia Utara penyebaran bulu babi mencapai hingga 316 jenis sedangkan pada perairan Indonesia sendiri ditemukan 84 jenis bulu babi yang berasal dari 48 marga dan 21 suku (Aziz, 1987 dalam Akerina, 2015 ). Bulu babi banyak terdapat atau ditemui pada kedalaman 2 meter hingga mencapai 30 meter di bawah permukaan laut, tetapi ada juga hingga mencapai 100 meter di bawah permukaann laut (Kelly, Hughes, \& Cook, 2007 dalam Yulianto, 2012). Wilayah Maluku khususnya Kabupaten Maluku Tengah memiliki potensi tinggi sebagai penghasil bulu babi (Dinas Perhubungan, 
Komunikasi dan Informatika Kabupaten Maluku Tengah, 2013 dalam Hadinoto,2017). Terutama di wilayah khususnya di perairan Liang, Sila dan Waai Kabupaten Maluku Tengah, di lokasi atau di wilayah tersebut bulu babi belum dapat dimanfaatkan secara optimal, bahkan lebih parahnya bulu babi dilokasi tersebut dibuang karena takut melukai masyarakat nelayan yang mencari ikan dan anak -anak yang ingin bermain di sekitar pantai ( Hadinoto,2017).

Bulu babi termasuk dalam Filum Echinodermata, kelas Echinoidea yang merupakan hewan laut yang berbentuk bulat, memiliki duri pada permukaan kulitnya yang dapat digerakkan (Wulandewi, 2015) dan memiliki sisi tubuh berbentuk segi lima (simetris radial), dengan cangkang keras berkapur (Kuncoro, 2004 dalam Arhas, 2018). Duri ini digunakan untuk bergerak, melindungi diri, serta mencapit makanan, dan ada juga jenis duri tertentu yang mengandung racun. Toksin yang dihasilkan pada bulu babi tersebut dapat juga digunakan dalam bidang pengobatan yang berpotensi sebagai antibiotik (Abubakar et al, 2012 dalam Indrawati, 2018). Ini sesuai dengan pendapat Dahl, Jebson \& Louis,( 2010 dalam Hadinoto, 2016) diperkirakan racun yang terdapat dalam cangkang dan duri pada bulu tersebut juga dapat digunakan untuk bahan obat antara lain sebagai antimikroba, cangkang bulu babi juga memiliki kandungan senyawa bioaktif seperti glikosida, serotoin, brandykinin-like substances, steroid dan bahan cholinergic. Echinoidea (bulu babi) membersihkan tubuhnya dengan berjalan dengan menggerakkan duri-duri dan tentakelnya tersebut. Bersamaan dengan gerakan itu sisa-sisa bahan makanan dikeluarkan melalui anus. Hewan ini memakan berbagai macam makanan yang ada di laut, misalnya organisme kecil, rumput laut dan hewan mati, disamping itu juga bulu babi pemakan lumpur atau pasir yang mengandung bahan organik (Jasin, 1992 dalam AL JAMI , 2010. Mulut pada bulu babi mempunyai lima gigi kuat dan tajam yang berfungsi untuk mengunyah makanannya yang dikenal sebagai lentera ariestoteles (Aziz, 1987 dalam Huda 2016). Pada bagian aboral terdapat anus berwarna jingga dan terdapat warna biru atau hijau pada bagian genital, sedangkan pada bagian oral terdapat mulut. Bulu babi mempunyai lima deret kaki tabung yang digunakan untuk pergerakan yang lambat. Bulu babi mempunyai otot yang dapat memutar duri-durinya yang panjang (Campbell, 2012 dalam Wibowo, 2016).

Bulu babi merupakan sumberdaya perikanan yang memiliki nilai ekonomi yang tinggi (Nane, 2019a). Telur bulu babi/gonad telah menjadi komoditi penting di negara-negara tertentu seperti Jepang, Kanada (British Columbia), USA, dan lain-lain (Kato dan Schroeter, 1985 dalam Toha, 2006; Nane, 2019c). Produk ini dikenal dengan -unill mempunyai harga yang cukup sangat mahal. Untuk satu kilogram uni harganya berkisar antara 50 - 500 US dolar, yang dinilai dari kualitas telur, terutama warna dan tekstur (Zakaria,2013). Bulu babi memiliki Sel telur yang berbentuk bola, terdiri dari inti sel, sitoplasma beserta kuning telur dan dikelilingi oleh membran vitelin. Telur bulu babi teksturnya terasa lembut dan lezat serta mempunyai nilai gizi yang cukup tinggi (Zakaria,2013). 
Telur bulu babi adalah makanan bernilai gizi tinggi yang mengandung protein 15,43 \% hingga mencapai 25,67 \%. Kandungan lemak total telur Echinometra Sp. 6,2 \% dan T Gartilla adalah $5,7 \%$. Kadar asam lemak larut paling kecil dan paling tinggi yaitu asam palmitat (28,254\%). kadar kalsium paling tinggi terdapat pada gonad Mespilia globulus (8,69\%); kadar seng paling tinggi pada gonad Tripneustes gratilla (3,0\%) (Wiralis, 2017). Gonad bulu babi jenis D. setosum mengandung 18 jenis asam lemak tak jenuh, termasuk omega-3 dan omega- 6 serta 15 jenis asam amino (Afifudin, Suseno, dan Jacoeb, 2014 dalam Hadinoto,2017). Gonad pada bulu babi belum menjadi bahan makanan pendamping ASI (MP-ASI) karena faktor pengetahuan yang kurang memadai. Intervensi ini diarahkan untuk menguatkan konsumsi sebagai nilai tambah bahwa budaya makan gonad bulu babi pada anak balita merupakan sumber protein yang murah dan mudah didapatkan sebagai menu keluarga dan dapat mengatasi masalah kurang gizi, gizi buruk dan dapat juga digunakan sebagai bahan makanan pendamping ASI (Wiralis, 2017).

Gonad bulu babi di luar negeri menjadi makanan yang popular dengan nilai perdagangan yang cukup baik, dipasarkan dalam bentuk produk beku, produk segar, produk kering ada juga dalam produk asin, maupun sampai produk kalengan berupa pasta yang di fermentasikan (Tupan dan Silaban, 2017 dalam Sadam, 2019). Sedangkan, pemanfaatan pada gonad bulu babi di indonesia tersebut sebagai bahan makanan yang sebenarnya sudah dilakukan sejak lama misalnya di Wakatobi (Nane, 2019b). Biasanya dikonsumsi dalam bentuk segar atau dalam keadaan yang sudah dimasak misalnya dikukus, digoreng dan ada juga dibakar (Chasanah dan Andamari 1997 dalam Silaban, 2014).

Bagian dari bulu babi khususnya pada Cangkang dan gonadnya diketahui memiliki nilai ekonomi yang tinggi. Diketahui Cangkang dan duri ini dapat digunakan sebagai pupuk organik, pewarna, hiasan adapun juga dalam bidang kesehatan bulu babi digunakan untuk mongobati penyakit (Toha 2007) dan memiliki potensi sebagai, antitumor, antimikroba dan antikanker (Aprillia et al. 2012 dalam Silaban, 2014). Beberapa ahli menggunakan bulu babi sebagai salah satu organisme paling banyak digunakan untuk mempelajari biologi khususnya reproduksi (Vacquier et al., 1995 dalam Toha, 2019), toksikologi (Dinnel et al., 1989 dalam Toha, 2019), biologi evolusi (Peterson et al., 2000 dalam Toha, 2019), regulasi gen (Davidson et al., 2002), dan embriologi (Davidson et al., 1998; Lee et al., 1999 dalam Toha, 2019).

\section{Conclusion}

Dapat disimpulkan bahwa di indonesia terkenal memiliki banyak ekosistem dan manfaat sumber daya alam seperti makanan, sumber kehidupan, sumber mineral, dan kawasan pariwisata, serta 
memiliki ekosistem produktivitas primer relative tinggi pada ekosistem seperti pasir, air laut, mikroorganisme, mangrove, terumbu karang dan padang lamun serta biota laut yang berasosiasi disalah satu bulu babi, bulu babi merupakan biota termasuk dalam kelompok echinodermata kemudian termasuk salah satu spesies bagi terumbu karang dan penentu kelimpahan dan sebaran tumbuhan di laut yang dangkal, bulu babi adalah salah satu pengendali populasi mikroalga dan pada umumnya bulu babi adalah hewan nocturnal yang aktif pada malam hari untuk mencari makanan dan setiap jenis bulu babi mempunyai sebaran habitat yang spesifik atau khusus. Khusus untuk spesies E. Mathae dan E. calamaris mereka hidup untuk menghindari diri dari predator.jadi. bulu babi dapat hidup tumbuh dan menyebardi perairan pantai dengan lingkungan yang mempengaruhinya . dari beberapa wilayah negara perairan hanya memiliki 316 jenis penyebaran bulu babi terdapat pada kedalaman 2-3 meter bahkan 100 meter permukaan laut serta wilayah yang memiliki penghasilan bulu babi yang tinggi yaitu wilayah Maluku khususnya kabupaten Maluku tengah dan di wilayah yang belum dimanfaatkan secara optimal yaitu perairan sila, liang dan waai kabupaten Maluku tengah karena takut melukai masyarakat nelayan yang mencari ikan dan anakanak yang ingin bermain disekitaran pantai. Bentuk bulu babi yaitu bulat memiliki duri pada permukaan kulitnya yng bisa digerakkan, bentuk simetris radial dan durinya digunakan untuk berger ak, melindungi diri serta mencapit makanan dan ada juga yang mengandung racun. Toksin memiliki manfaat untuk pengobatan sebagai antibiotic. Racun pada cangkang dan duri dapat digunakan sebagai obat antimikroba cangkang pada bulu babi memiliki senya bioaktif seperti serotin,glikosida, steroid, bahan cholinergic dan brandykinin-like substances. Echinoidae (bulu babi) membersihkan tubuhnya berjalan mengerakan duri-duri dan tentakelnya kemudian bersamaan dengan sisa-sisa makanan yang dikeluarkan melalui anus. Bulu babi juga memakan hewan yang sudah mati, organisme kecil dan rumput laut dan mulut bulu babi juga memiliki lima gigi tajam yang berfungsi mengunyah makanan pada bagian aboralnya terdapat anus yang berwana jinggadan biru atau hijau pada bagian genital sedangkan pada bagian oral mulut babi mempunyai lima deret kaki tabung untuk digerakan dengan lambat. Bulu babi mempunyai otot untuk memutar duri-durinya yang panjang. Bulu babi memiliki nilai ekonomi yang sangat tinggi karena telur/gonad yang menjadi komiditi yang penting penting di negara- negara tertentu seperti Jepang, Kanada (British Columbia), USA, dan lain-lain serta mempunyai harga yang sangat mahal, bisa mencapai 50-500 US dolar/kg karena dinilai dari kualitas telur, terutama warna dan tektur. Bulu babi memiliki Sel telur berbentuk bola, terdiri dari inti sel, sitoplasma beserta kuning telur dan dikelilingi oleh membran vitelin. Telur bulu babi terasa lembut dan lezat serta mempunyai nilai gizi yang tinggi. Telur bulu babi mempunyai nilai gizi yang tinggi mengandung protein 15,43 \% - 25,67 \%. Kandungan lemak total Sp. 6,2 \% dan T Gartilla adalah 5,7 \%. Kadar asam lemak larut paling kecil dan paling tinggi yaitu asam palmitat (28,254\%). kadar kalsium paling tinggi terdapat pada gonad Mespilia globulus (8,69\%), kadar seng 
paling tinggi pada gonad Tripneustes gratilla (3,0\%). Gonad pada balita mengandung manfaat sumber protein yang murah dan mudah didapatkan sebagai menu keluarga dan dapat digunakan sebagai bahan bahan makanan pendamping ASI. Gonad di luar negeri smenjadi makanan popular dengan nilai perdagangan yang baik, dibentu produk segar, produk beku, produk asin, produk kering,dan produk kalengan berupa pasta fermentasi sedangkan gonad bulu babi di indonesia sebagai bahan makanan yang sebenarnya sudah dilakukan sejak lama, biasa dikonsumsi dalam bentuk segar atau yang sudah dimasak misalnya digoreng, dibakar, dan dikukus. Bagian bulu babi khususnya pada Cangkang dan gonad memiliki nilai ekonomi yang tinggi. Cangkang dan duri bisa digunakan untuk hiasan, pupuk organik, pewarna, serta dalam bidang kesehatan karena bulu babi digunakan untuk mongobati penyakit.

\section{References}

Afifa, F. H., Supriharyono, S., \& Purnomo, P. W. (2018). Penyebaran Bulu Babi (Sea Urchins) Di Perairan Pulau Menjangan Kecil, Kepulauan Karimunjawa, Jepara. Management of $\begin{array}{llll}\text { Aquatic } & \text { Resources } & \text { 230urnal, } 338 .\end{array}$ https://ejournal3.undip.ac.id/index.php/maquares/article/view/20580

Al-Jami, A. H. (2010). Skrining Senyawa Antimitosis Ekstrak Daun Waru (Hibiscus Tiliaceus L.) Berdasarkan Penghambatan Pembelahan Sel Telur Bulubabi [Doctoral dissertation, Universitas Islam Negeri Alauddin Makassar].

Arhas, F. R., Mahdi, N., \& Kamal, S. (2018). Struktur Komunitas Dan Karakteristik Bulu Babi (Echinoidea) Di Zona Sublitoral Perairan Iboh Kecamatan Sukakarya Kota Sabang. Prosiding Biotik, 2(1).

Ayuwati, R. N. (2017). Pola Distribusi Jenis Echinoidea Di Zona Intertidal Tanjung Bilik Taman Nasional Baluran.

Silaban, B., \& Srimariana, E. S. (2014). Kandungan Nutrisi Dan Pemanfaatan Gonad Bulu Babi (Echinothrixs Calamaris) Dalam Pembuatan Kue Bluder. Jurnal Pengolahan Hasil Perikanan Indonesia, 16(2).

Firmandana, T. C. (2014). Kelimpahan Bulu Babi (Sea Urchin) pada Ekosistem Karang dan Lamun di Perairan Pantai Sundak, Yogyakarta. Management of Aquatic Resources Journal, 3(4), 4150. https://ejournal3.undip.ac.id/index.php/maquares/index

Fitriansyah, M. (2018, October). Identifikasi echinodermata di pesisir Pulau Denawan, Kecamatan Pulau Sembilan. In Prosiding Seminar Nasional Lingkungan Lahan Basah, 3(1). http://snllb.ulm.ac.id/prosiding/index.php/snllb-lit/article/view/36/36 
Hadinoto, S., Sukaryono, I. D., \& Siahay, Y. (2017). Kandungan Gizi Gonad dan Aktivitas Antibakteri Ekstrak Cangkang Bulu Babi (Diadema setosum). Jurnal Pascapanen dan Bioteknologi Kelautan dan Perikanan, 12(1), 71-78.https://bbp4b.litbang.kkp.go.id/jurnaljpbkp/index.php/jpbkp/article/view/281

Hadinoto, S., Sukaryono, I. D., \& Siahay, Y. Kandungan Gizi Bulu Babi (Diadema Setosum) Dan Potensi Cangkangnya Sebagai Antibakteri. Lambung Mangkurat University Press. http://eprints.ulm.ac.id/id/eprint/2803

Huda, M. A. I. (2016). Keanekaragaman Jenis Echinoidea di Zona Intertidal Pantai Jeding Taman Nasional Baluran.http://repository.unej.ac.id/handle/123456789/76681

Indrawati, I., Hidayat, T. R., \& Rossiana, N. (2018). Antibakteri dari Bulu Babi (Diadema setosum) Terhadap Escherichia coli dan Staphylococcus aureus. Jurnal Biodjati, 3(2), 183-192.https://journal.uinsgd.ac.id/index.php/biodjati/article/view/2410

Juliawan, J., Dewiyanti, I., \& Nurfadillah, N. (2017). Kelimpahan dan Pola Sebaran Bulu Babi (Echinodea) di Perairan Pulau Klah Kota Sabang. Jurnal IImiah Mahasiswa Kelautan Perikanan Unsyiah, 2(4). http://www.jim.unsyiah.ac.id/fkp/article/view/7777/3371

Lubis, S. A., Purnama, A. A., \& Yolanda, R. (2017). Spesies Bulu Babi (Echinoidea) Di Perairan Pulau Panjang Kabupaten Bangka Tengah Provinsi Bangka Belitung. Jurnal IImiah Mahasiswa FKIP Prodi Biologi, 3(1). http://e-journal.upp.ac.id/index.php/fkipbiologi/article/view/1134

Miala, I., Pratomo, A., \& Irawan, H. (2015). Hubungan Antara Bulu Babi, Makroalgae Dan Karang Di Perairan Daerah Pulau Pucung. Repository UMRAH.

Moningkey, R. D. (2010). Pertumbuhan populasi bulu babi (Echinometra mathaei) di perairan pesisir Kima Bajo Kabupaten Minahasa Utara. Jurnal Perikanan dan Kelautan Tropis, 6(2), 73-78. https://ejournal.unsrat.ac.id/index.php/JPKT/article/view/164

Morfologi, S. Short Communication Penentuan Jenis Kelamin Bulu Babi Tripneustes gratilla Secara Morfologi.

Nane, L. (2019a). Efisiensi Mesin Teknologi Sapurata Dalam Mengoptimalisasi Produksi Inovasi Pangan Kukure Di Pulau Barrang Lompo, Makassar. https://doi.org/10.31230/osf.io/q8spg

Nane, L. (2019b). Impact of overfishing on density and test-diameter size of the sea urchin Tripneustes gratilla at Wakatobi Archipelago, south-eastern Sulawesi, Indonesia. BioRxiv, 727271. https://www.biorxiv.org/content/10.1101/727271v1

Nane, L. (2019c). Sea Urchin Sustainability Studies Based on Dimension Biology, Ecology and Technology at Around of Tolandono Island and Sawa Island at Wakatobi Conservation Area. https://doi.org/10.31230/osf.io/4whz6 
Nane, L., Baruadi, A. S. R., \& Mardin, H. (2020). The density of the blue-black urchin Echinotrix diadema (Linnaeus, 1758) in TominiBay, Indonesia. Tomini Journal of Aquatic Science, 1(1), 16-21. https://doi.org/10.37905/tjas.v1i1.5939

Nane, L. (2019d). Studi Keberlanjutan Perikanan Landak Laut Berdasarkan Dimensi Biologi, Ekologi Dan Teknologi Di Sekitar Pulau Tolandono Dan Pulausawa Kawasan Konservasiwakatobi [Skripsi], Universitashasanuddin, Makassar. Https://Marxiv.Org/9zdvr/

Purwandatama, R. W., \& Ain, C. (2013). Kelimpahan Bulu Babi (Sea Urchin) pada Karang Massive dan Branching di Daerah Rataan dan Tubir di Legon Boyo, Pulau Karimunjawa, Taman Nasional Karimunjawa. Management of Aquatic Resources Journal, 3(1), 17-26. https://ejournal3.undip.ac.id/index.php/maquares/article/view/4282

Puspitaningtyas, I. H., Rudiyanti, S., \& Sulardiono, B. (2018). Aspek Reproduksi Bulu Babi (Sea Urchin) Di Perairan Pulau Menjangan Kecil, Kepulauan Karimunjawa, Jepara (Aspects Reproduction of Sea Urchin in the Waters of Menjangan Kecil Island, Karimunjawa Islands, Jepara). Management of Aquatic Resources Journal, 6(4), 564- 571. https://ejournal3.undip.ac.id/index.php/maquares/article/view/21349

Riniatsih, I., \& Munasik, M. (2017). Keanekaragaman Megabentos yang Berasosiasi di Ekosistem Padang Lamun Perairan Wailiti, Maumere Kabupaten Sikka, Nusa Tenggara Timur. Jurnal Kelautan Tropis, 20(1),56-59.

https://ejournal2.undip.ac.id/index.php/jkt/article/view/1357/1010

Sadam, A.L.O. Emiyarti. Ira.(2019). Keanekaragaman Bulu Babi (Echinoidea) Pada Kawasan Lamun Di Perairan Desa Langara, Kecamatan Wawonii Barat Kabupaten Konawe Kepulauan, 4(3):113-122. http://ojs.uho.ac.id/index.php/JSL/article/view/8775

Setyawan, B., Sulardiono, B., \& Purnomo, P. W. (2014). Kelimpahan Bulu Babi (Sea Urchin) pada Ekosistem Terumbu Karang dan Ekosistem Padang Lamun di Pulau Panjang, Jepara. Management of Aquatic Resources Journal, 3(2), 74-81. https://ejournal3.undip.ac.id/index.php/maquares/index

Somma, A., Zahida, F., \& Yuda, P. (2018). Kelimpahan dan Pola Penyebaran Bulu Babi (Echinoidea) di Terumbu Karang Pantai Pasir Putih, Situbondo, Indonesia. Biota: Jurnal IImiah IImuIImu Hayati, 3(2), 111-115. http://ojs.uajy.ac.id/index.php/biota/article/view/1887

Supriharyono, S., Afifa, F. H., \& Purnomo, P. W. (2018). Penyebaran Bulu Babi (Sea Urchins) Di Perairan Pulau Menjangan Kecil, Kepulauan Karimunjawa, Jepara. Management of $\begin{array}{lll}\text { Aquatic Resources 6(3),230-238. } & \text { Journal, }\end{array}$ https://ejournal3.undip.ac.id/index.php/maquares/article/view/20580

Toha, A. H. A. (2019). Keragaman genetik bulu babi (Echinoidea). Biota: Jurnal IImiah IImu-IImu Hayati, 12(2), 131-135. http://ojs.uajy.ac.id/index.php/biota/article/view/2669 
Triana, R., Elfidasari, D., \& Vimono, I. B. (2015, June). Indentification of Echinoderms in southern Pulau Tikus, Gugusan Pulau Pari, Kepulauan Seribu, Jakarta. In Prosiding Seminar Nasional $\begin{array}{llll}\text { Masyarakat } \quad \text { Biodiversitas } & \text { 45donesia }\end{array}$ https://smujo.id/files/psnmbi/M0103/M010313.pdf

Wibowo, G. J. (2016). Struktur Komunitas Biota Hewan Di Padang Lamun Pantai Sindangkerta Kecamatan Cipatujah Kabupaten Tasikmalaya (Doctoral dissertation, FKIP UNPAS). http://repository.unpas.ac.id/10767/

Wiralis, W., Fathurrahman, T., Hariani, H., \& Nugraheni, W. P. (2017). Edukasi Gizi Untuk Peningkatan Kualitas Menu Anak Balita Dengan Konsumsi Gonad Bulu Babi (Sea Urchins) Sebagai Alternatif Sumber Protein Pada Keluarga Etnik Bajo Soropia. Gizi Indonesia, 40(2), 69-78.

Wulandewi, N. L. E., Subagio, J. N. J. N., \& Wiryatno, J. (2015). Jenis dan Densitas Bulu Babi (Echinoidea) Di Kawasan Pantai Sanur dan Serangan Denpasar-Bali. SIMBIOSIS, 3(1). https://ojs.unud.ac.id/index.php/simbiosis/article/view/14406/9902

Yudasmara, G. A. (2013). Keanekaragaman Dan Dominansi Komunitas Bulu Babi (Echinoidea) Di Perairan Pulau Menjangan Kawasan Taman Nasional Bali Barat. JST (Jurnal Sains dan Teknologi), 2(2). http://dx.doi.org/10.23887/jst-undiksha.v2i2.2897

Yulianto, A. R. (2012). Pemanfaatan Bulu Babi secara Berkelanjutan pada Kawasan Padang Lamun. [Thesis. Universitas Indonesia. Thesis (Tidak dipublikasikan). http://www.academia.edu/download/32436096/Draft_final.pdf

Zakaria, I. J. (2013). Komunitas Bulu Babi (Echonoidea) di Pulau Cingkuak, Pulau Sikuai dan Pulau Setan Sumatera Barat. Prosiding SEMIRATA 2013, 1(1). http://jurnal.fmipa.unila.ac.id/semirata/article/view/681 